\title{
Ficolins: Complement-Activating Lectins Involved in Innate Immunity
}

\author{
Misao Matsushita \\ Department of Applied Biochemistry, Tokai University, Hiratsuka, Japan
}

\section{Key Words}

Complement $\cdot$ Carbohydrates $\cdot$ Ficolins $\cdot$ Homeostasis . Innate immunity $\cdot$ Lectin pathway $\cdot \mathrm{MBL}$-associated serine protease $\cdot$ Pattern recognition molecules

\begin{abstract}
Ficolins are a group of oligomeric lectins with subunits consisting of both collagen-like and fibrinogen-like domains. The majority of ficolins identified in vertebrates and invertebrates to date recognize $\mathrm{N}$-acetylglucosamine (GICNAc). $\mathrm{X}$-ray crystallographic analysis of human ficolins has shown that the fibrinogen-like domain binds to the $\mathrm{N}$-acetylated moiety. Ficolins in serum are associated with MBL-associated serine protease (MASP). The ficolin-MASP complex binds directly to carbohydrates present on the surface of a variety of Gram-positive and Gram-negative bacteria through ficolin. Binding of the complex initiates complement activation via the lectin pathway, leading to generation of opsonic fragments of complement components, such as C $3 \mathrm{~b}$, and to lysis of the bacteria by the membrane attack complex. Thus, serum ficolins play an important role in innate immunity.
\end{abstract}

Copyright $\odot 2009$ S. Karger AG, Basel

\section{Introduction}

In 1993, two new transforming growth factor- $\beta 1$ binding proteins from pig uterus membranes were cloned and characterized [1]. They had a unique chimeric structure consisting of collagen-like and fibrinogen-like domains and were termed ficolin $\alpha$ and ficolin $\beta$. The collagen-like domain sequence contains glycine residues at every third position. The fibrinogen-like domain consists of approximately 230 amino acids similar to the $\mathrm{COOH}$ terminal halves of fibrinogen $\beta$ and $\gamma$ chains. Since the first report on pig ficolins, many proteins having this chimeric structure have been discovered in both vertebrates and invertebrates (table 1).

Accumulating evidence shows that ficolins constitute a family of lectins, the majority of which bind to $\mathrm{N}$-acetylated saccharides such as $N$-acetylglucosamine (GlcNAc). Ficolins have tissue-dependent distributions, suggesting that their functions are also tissue-specific. To date, ficolins in serum have been intensively characterized and found to act as pattern recognition molecules that recognize carbohydrates on the surface of microbial pathogens. Following pathogen recognition, serum ficolins activate the complement system - an effector system in host defense - thereby playing a crucial role in innate immunity [2]. This review discusses ficolins with a focus on their ability to activate complement and their role in innate immunity.

\section{KARGER \\ Fax +4161306 1234 E-Mail karger@karger.ch} www.karger.com
Prof. Dr. Misao Matsushita

Department of Applied Biochemistry

Tokai University, 1117 Kitakaname

Hiratsuka, Kanagawa 259-1292 (Japan)

Tel. +81 46358 1211, Fax +81 46350 2012, E-Mail mmatsu@keyaki.cc.u-tokai.ac.jp 
Table 1. Characteristics of ficolins

\begin{tabular}{|c|c|c|c|c|c|}
\hline Species & Ficolins & mRNA expression & Protein identified & Binding substance & Function \\
\hline \multirow[t]{3}{*}{ Human } & L-ficolin & liver & serum/plasma & $\begin{array}{l}\text { GlcNAc (acetyl group); } \\
\beta \text {-( }(\rightarrow 3) \text {-D-glucan; } \\
N \text {-acetylneuraminic acid; } \\
\text { lipoteichoic acid; C-reactive } \\
\text { protein; fibrinogen, fibrin; } \\
\text { DNA; elastin;corticosteroid }\end{array}$ & $\begin{array}{l}\text { complement activation; } \\
\text { opsonin }\end{array}$ \\
\hline & H-ficolin & $\begin{array}{l}\text { liver, lung, } \\
\text { glioma cell }\end{array}$ & $\begin{array}{l}\text { serum/plasma, bile duct, } \\
\text { bronchus, alveolus }\end{array}$ & $\begin{array}{l}\text { GlcNAc, GalNAc, fucose; } \\
\text { lipopolysaccharide; } \\
\text { polysaccharide preparations }\end{array}$ & $\begin{array}{l}\text { complement activation; } \\
\text { opsonin }\end{array}$ \\
\hline & M-ficolin & $\begin{array}{l}\text { lung, monocyte, } \\
\text { spleen }\end{array}$ & $\begin{array}{l}\text { plasma, monocyte, neutro- } \\
\text { phil, alveolar epithelial cell }\end{array}$ & GlcNAc, GalNAc; sialic acid & $\begin{array}{l}\text { complement activation; } \\
\text { phagocytic receptor }\end{array}$ \\
\hline \multirow[t]{2}{*}{ Mouse } & Ficolin A & liver, spleen & serum/plasma & GlcNAc, GalNAc; elastin & complement activation \\
\hline & Ficolin B & bone marrow, spleen & macrophage & GlcNAc, GalNAc; sialic acid & opsonin \\
\hline \multirow[t]{2}{*}{ Pig } & Ficolin $\alpha$ & $\begin{array}{l}\text { liver, lung, } \\
\text { bone marrow }\end{array}$ & $\begin{array}{l}\text { serum/plasma, } \\
\text { uterus membranes }\end{array}$ & $\begin{array}{l}\text { GlcNAc; lipopolysaccharide, } \\
\text { lipoteichoic acid, elastin; TGF- } \beta 1\end{array}$ & antiviral activity \\
\hline & Ficolin $\beta$ & $\begin{array}{l}\text { neutrophil, } \\
\text { bone marrow }\end{array}$ & $\begin{array}{l}\text { neutrophil, } \\
\text { uterus membranes }\end{array}$ & TGF- $\beta 1$ & ND \\
\hline Hedgehog & Erinacin & ND & muscle & metalloprotease & antihemorrhagic activity \\
\hline \multirow[t]{4}{*}{ Xenopus } & XeFCN1 & liver, spleen, heart & serum & GlcNAc, GalNAc & ND \\
\hline & $\mathrm{XeFCN} 2$ & lung, spleen, leukocyte & NI & ND & ND \\
\hline & XeFCN3 & ND & NI & ND & ND \\
\hline & $\mathrm{XeFCN} 4$ & lung, spleen & NI & ND & ND \\
\hline \multirow[t]{2}{*}{ Ascidian } & $\mathrm{p} 40$ & hepatopancreas & hemolymph plasma & GlcNAc, GalNAc & ND \\
\hline & p50 & hepatopancreas & hemolymph plasma & GlcNAc & ND \\
\hline
\end{tabular}

$\mathrm{ND}=$ Not determined NI = not identified .

\section{Human Ficolins}

Three types of ficolins, $\mathrm{L}, \mathrm{H}$ and $\mathrm{M}$, are present in humans.

\section{L-Ficolin}

L-ficolin (synonymous with L-ficolin/P35, ficolin 2, ficolin L, EBP-37, or hucolin) is an oligomeric protein consisting of $35-\mathrm{kDa}$ subunits [3]. Each subunit is composed of an $\mathrm{NH}_{2}$-terminal region with 2 cysteine residues (Cys7 and Cys27), which is followed by a collagen-like sequence and the $\mathrm{COOH}$-terminus of a fibrinogen-like domain (fig. 1). The fibrinogen-like domain is globular, and the overall structure of L-ficolin resembles a 'bou- quet'. The proposed structure is a tetramer consisting of 4 triple helices formed by 12 subunits [4]. The oligomeric structure of L-ficolin is formed by the crosslinking of subunits via disulfide bridges involving Cys7 and Cys27 residues.

The L-ficolin gene (FCN2) is located on chromosome $9 q 34$ and contains 8 exons [5]. The mRNA of L-ficolin is mainly expressed in the liver and its protein product is secreted into serum.

L-ficolin exhibits lectin activity toward GlcNAc [3]. Lficolin has been found to recognize an acetyl group [6-8]. It also binds to $\beta$ - $(1 \rightarrow 3)$-D-glucan [9]. Binding sites for carbohydrates are located in the fibrinogen-like domain. $\mathrm{X}$-ray crystallographic analysis of the fibrinogen-like do- 


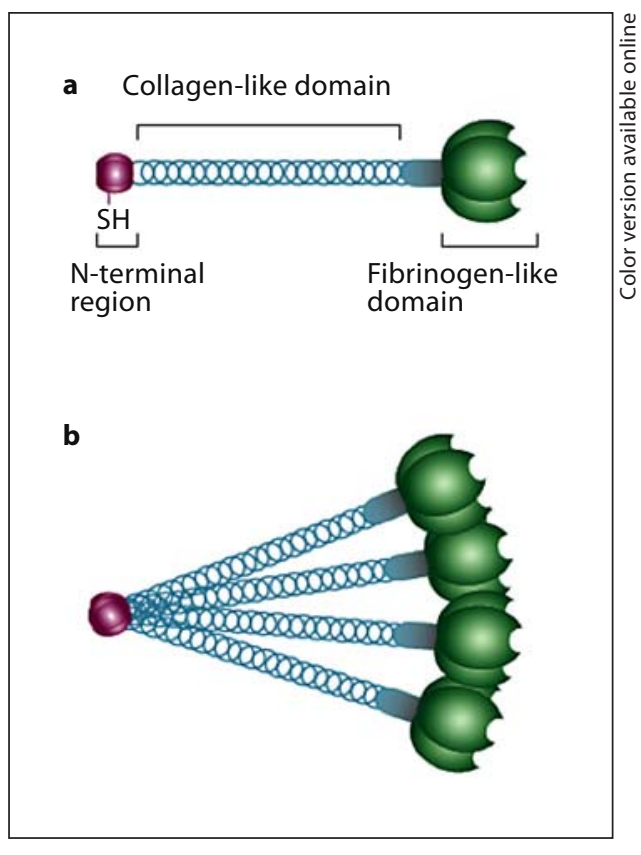

Fig. 1. Structure of ficolin. a Domain structure. b The tetrameric structure consisting of 12 subunits proposed for L-ficolin.

main in complex with various ligands has revealed that L-ficolin has 4 different sites involved in binding for $\mathrm{N}$ acetylated carbohydrates and neutral carbohydrates such as $\beta$-(1 $1 \rightarrow 3)$-D-glucan [10]. Two single nucleotide polymorphisms, which result in the substitution of threonine with methionine at codon 236 and alanine for serine at codon 258, have been found in exon 8 of FCN2 [11, 12]. These polymorphisms are associated with decreased and increased GlcNAc binding, respectively, in comparison to wild type L-ficolin.

L-ficolin binds to Salmonella typhimurium TV119, which is an Ra chemotype strain containing a lipopolysaccharide with a GlcNAc residue at the non-reducing terminus. It also binds to Escherichia coli, several capsulated Staphylococcus aureus serotypes, and capsulated Staphylococcus pneumoniae serotypes; however, L-ficolin does not bind to noncapsulated strains of bacteria. In addition to its lectin activity, L-ficolin has been reported to bind to elastin [13] and corticosteroids [14].

\section{H-Ficolin}

$\mathrm{H}$-ficolin (synonymous with Hakata antigen, ficolin $\mathrm{H}$, ficolin 3 , or $\beta 2$ thermolabile macroglycoprotein) was first identified as a serum antigen recognized by an autoantibody present in patients with systemic lupus erythe- matosus [15]. H-ficolin is an oligomer of 34-kDa subunits and exhibits more than 10 bands on SDS-PAGE under nonreducing conditions, thereby suggesting a mixture of oligomers of different sizes [16].

The H-ficolin gene (FCN3) is located on chromosome 1 p35.3 and consists of 8 exons with similar organization as the L-ficolin gene. H-ficolin mRNA is expressed in the liver and lung. In the liver, $\mathrm{H}$-ficolin is produced by bile duct epithelial cells and hepatocytes and is secreted into bile and serum [17]. In the lungs, $\mathrm{H}$-ficolin is produced by both ciliated bronchial epithelial cells and type II alveolar epithelial cells and is secreted into the bronchus and alveolus. $\mathrm{H}$-ficolin is also produced in glioma cell lines [18].

$\mathrm{H}$-ficolin has been shown to bind to GlcNAc, $\mathrm{N}$-acetylgalactosamine (GalNAc), and fucose, but not to mannose and lactose [19]. Apparently, however, the binding affinity of H-ficolin for GlcNAc may be very weak compared to that of L-ficolin. In accordance with this supposition, structural studies demonstrated that the fibrinogen-like domain of $\mathrm{H}$-ficolin could not be co-crystallized with any of the acetylated compounds under investigation, including GlcNAc [10].

$\mathrm{H}$-ficolin agglutinates human erythrocytes coated with lipopolysaccharide derived from S. typhimurium, Salmonella Minnesota and Escherichia coli (O111) [19]. Studies to date have shown that the only bacterium to which $\mathrm{H}$-ficolin binds is Aerococcus viridans; $\mathrm{H}$-ficolin binds to polysaccharide preparations (PSA) derived from this bacterium, which are composed of glucose, mannose, GlcNAc, and xylose [20]. However, the chemical moiety in PSA that is recognized by $\mathrm{H}$-ficolin remains unknown because none of the monosaccharides inhibit $\mathrm{H}$-ficolin binding to PSA.

\section{M-Ficolin}

M-ficolin (synonymous with L-ficolin/P35 related protein, ficolin $\mathrm{M}$ or ficolin 1) mRNA is expressed in monocytes, the lungs and the spleen [5, 21-23]. The Mficolin gene (FCN1) is located on chromosome 9q34, as is $\mathrm{L}$-ficolin, and its exon organization resembles that of Lficolin [5]. M-ficolin has an extra exon encoding an additional segment of 4 Gly-Xaa-Yaa repeats. M-ficolin is reported to be expressed on the surface of peripheral blood monocytes and promonocytic U937 cells [23]. In contrast, M-ficolin has been found to be located in secretory granules in the cytoplasm of peripheral neutrophils and monocytes and in type II alveolar epithelial cells in the lungs, suggesting that $\mathrm{M}$-ficolin is a secretory protein [24]. In accordance with this supposition, M-ficolin has 
recently been found to be present in human plasma at very low levels [25].

Recombinant $\mathrm{M}$-ficolin exhibits binding activity toward acetylated compounds, including GlcNAc, GalNAc and sialic acid $[24,26]$, and it binds to bacteria including S. aureus and S. typhimurium LT2. Crystallization analysis supports the binding specificity for acetylated compounds [10].

\section{Ficolins of Nonhuman Species}

Besides human ficolins, proteins belonging to the ficolin family have been isolated from several vertebrates, including mice, pigs and Xenopus, and from the invertebrate ascidians (table 1 ).

Mice have 2 types of ficolins (ficolin A and ficolin B). Ficolin A mRNA is highly expressed in liver and spleen. The ficolin A protein is present in serum as a tetramer with 12 subunits [27], and it binds to GlcNAc [27] and elastin [28]. Ficolin B mRNA is expressed in bone marrow and spleen. The ficolin B protein is reported to be localized in lysosomes of activated macrophages [29]. Recombinant ficolin A and ficolin B exhibit lectin activities toward GlcNAc and GalNAc, whereas ficolin B also recognizes sialic acid like human M-ficolin [30]. Both ficolin $\mathrm{A}$ and $\mathrm{B}$ genes are located on chromosome 2A3. The ficolin $B$ gene is close to the region homologous to the human $\mathrm{L}$-ficolin and M-ficolin gene locus. The ficolin A gene consists of 10 exons, while ficolin B consists of 9 exons and its organization resembles that of the ficolin A gene, except it lacks the fifth exon. The exon organization of the ficolin B gene is very similar to that of the M-ficolin gene. It is speculated that ficolin A and ficolin B are homologous to human L-ficolin and M-ficolin, respectively. The mouse homologue of the $\mathrm{H}$-ficolin gene exists as a pseudogene on chromosome 4 [31].

\section{Three Activation Pathways of the Complement System}

The complement system consists of many proteins involved in a chain reaction of proteolysis and protein complex assembly that culminates in the elimination of the invading pathogens. It is activated via 3 pathways (the classical, alternative and lectin pathways; fig. 2). In the classical pathway, a collagenous subcomponent of the first component $(\mathrm{C} 1), \mathrm{Clq}$, binds to immunoglobulins within immune complexes, and this activates the associated serine proteases; $\mathrm{Cl} r$ is activated first, followed by $\mathrm{C} 1 \mathrm{~s}$. Activated $\mathrm{C} 1 \mathrm{~s}$ then cleaves $\mathrm{C} 4$ and $\mathrm{C} 2$ to generate $\mathrm{C} 3$ convertase $\mathrm{C} 4 \mathrm{bC} 2 \mathrm{a}$, which activates $\mathrm{C} 3$. The resulting C3b fragment not only acts as an opsonin but also initiates the formation of the membrane attack complex in the lytic pathway (C5 to C9). The alternative pathway consists of $\mathrm{C} 3$, properdin, factor $\mathrm{B}$, factor $\mathrm{D}$ and regulatory proteins, and is activated on the surface of pathogens without involvement of immunoglobulins. The classical and alternative pathways are involved in adaptive immunity and innate immunity, respectively.

The lectin pathway was first discovered as a third activation pathway of complement mediated by the mannose-binding lectin (MBL) [32]. MBL is an oligomeric lectin with identical subunits; each subunit consists of a collagen-like domain and a carbohydrate-recognition domain. MBL oligomers are formed by disulfide bonds between subunits. MBL recognizes mannose, GlcNAc, glucose and fucose. Human MBL is complexed with 3 types of serine protease, named MBL-associated serine protease (MASP-1, MASP-2, MASP-3) and sMAP (also called MAp19) [33]. MASPs 1, 2 and 3 share the domain structures CUB1, EGF, CUB2, CCP1, CCP2 and the serine protease domain. This structure is also shared by $\mathrm{C} 1 \mathrm{r}$ and C1s of the classical pathway (fig. 3). Thus, MASP, $\mathrm{C} 1 \mathrm{r}$ and $\mathrm{C} 1 \mathrm{~s}$ constitute a subfamity of serine protease (MASP/C1r/C1s family). sMAP is a truncated protein of MASP-2 and consists of the first 2 modules (CUB1-EGF) of MASP-2 as well as an additional 4 amino acids at the C-terminus.

Upon binding of the MBL-MASP complex to carbohydrates on the surface of microorganisms, MASP-2 undergoes autoactivation, which is concomitant with the conversion from an unactivated pro-enzyme form (single polypeptide chain) to an active form (2 polypeptide chains linked by a disulfide bond), thereby acquiring proteolytic activity against C4 and C2 [34]. MASP-1 is reported to collaborate with MASP-2 in the generation of $\mathrm{C} 3$ convertase $\mathrm{C} 4 \mathrm{bC} 2 \mathrm{a}$ by activating $\mathrm{C} 2$ [35]. Another report has shown that MASP-1 functions to activate MASP-2 in the MBL-MASP complex [36]. MASP-3 and sMAP have been found to have a regulatory role in the lectin pathway [37, 38]. However, these functions of MASP-1, MASP-3 and sMAP in the complex have yet to be established. 


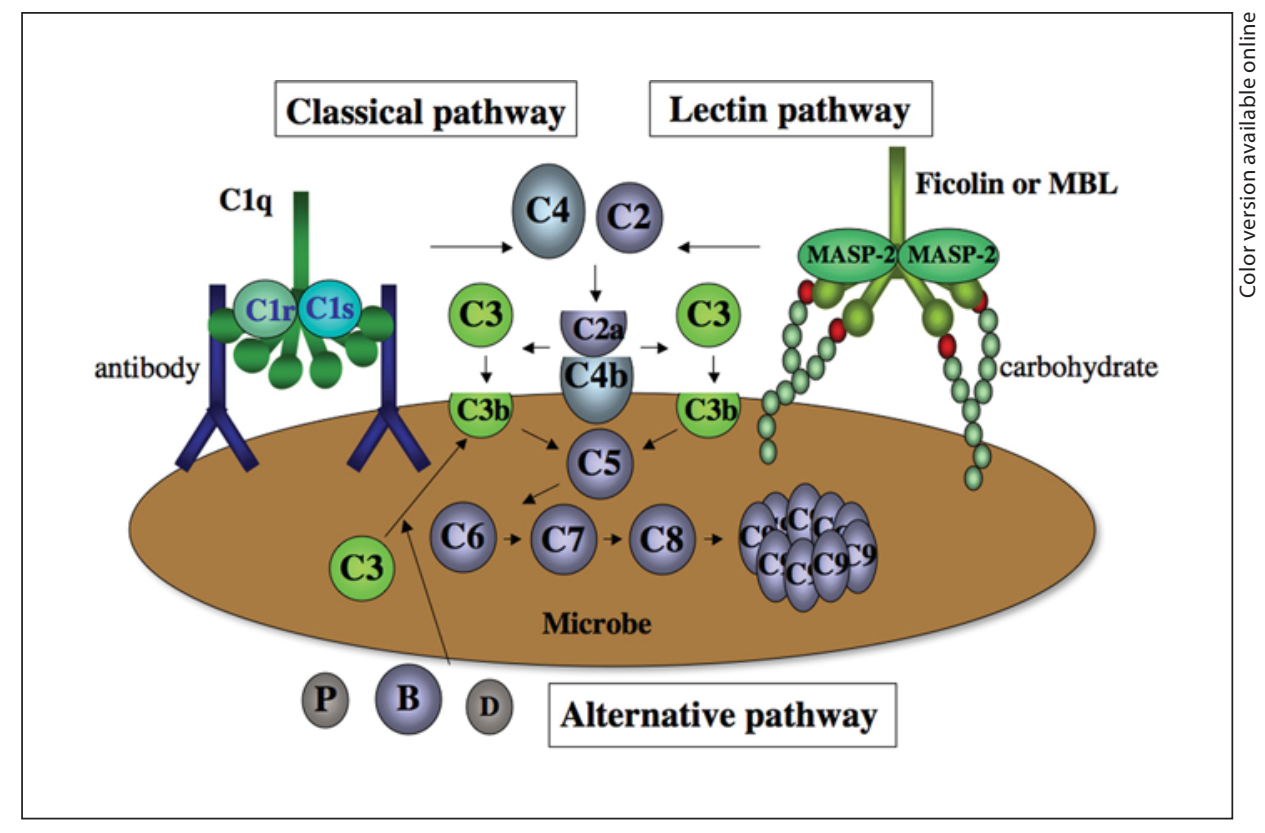

Fig. 2. Three activation pathways and the lytic pathway of the complement system. The lectin pathway is initiated by binding of the ficolin-MASP-2 complex or MBL-MASP-2 complex to carbohydrates on the surfaces of microbes. Although the lectins are complexed with MASP-1, MASP-3 and sMAP as well as with MASP-2, the roles of MASP-1, MASP-3 and sMAP in the lectin pathway have yet to be established. Therefore, these 3 components are not depicted in the figure. Activated MASP-2 in the complex cleaves $\mathrm{C} 4$ and $\mathrm{C} 2$, resulting in the formation of the $\mathrm{C} 3$ convertase
$\mathrm{C} 4 \mathrm{bC} 2 \mathrm{a}$. The classical pathway is initiated by binding of the $\mathrm{C} 1$ complex consisting of C1q, C1r and C1s to antigen-antibody complexes. Activated C1s cleaves $\mathrm{C} 4$ and C2, as does activated MASP2 in the lectin pathway. Interactions among $\mathrm{C} 3$, properdin $(\mathrm{P})$, factor $\mathrm{B}(\mathrm{B})$ and factor $\mathrm{D}$ (D) generate the alternative pathway C3 convertase, $\mathrm{C} 3 \mathrm{bBbP}$ (not shown in the figure), on microbes. In the lytic pathway, C5, C6, C7, C8 and C9 are sequentially activated. As a result, the polymerized $\mathrm{C} 9$ molecules form a pore in the membrane.

\section{Serum Ficolin-Mediated Activation of the Lectin Pathway}

Like MBL, L- and $\mathrm{H}$-ficolin present in human serum are complexed with the 3 MASPs and sMAP $[39,40]$. The binding sites on MASP-1 and MASP-3 for ficolins and MBL are located at the CUB1-EGF module [41]. Sequence alignments and site-directed mutagenesis studies have revealed that L-ficolin, H-ficolin and MBL share homologous binding sites for MASPs and calreticulin in the collagen-like regions [42]. Recent research has shown that recombinant M-ficolin also forms complexes with MASP1 and MASP-2 [24].

Comparison of MBL and 3 ficolins ( $\mathrm{L}, \mathrm{H}$ and $\mathrm{M}$ ) in terms of their ability to activate the lectin pathway revealed that $\mathrm{H}$-ficolin exhibited the greatest capacity. Lficolin and MBL had similar capacities. M-ficolin had minor activating potential [43]. The L-ficolin-MASP complex binds to acetylated LDL and activates C4 [7]. It also activates $\mathrm{C} 4$ upon binding to S. typhimurium TV119.

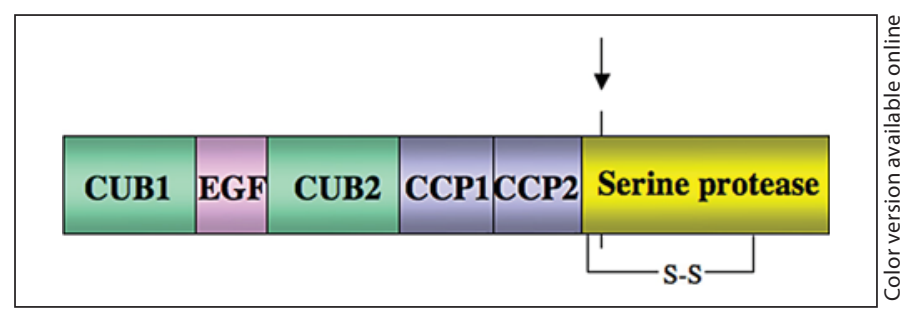

Fig. 3. Domain structure of the MASP/C1r/C1s family. The arrow indicates the site of peptide bond cleavage upon changing from an unactivated to an active form. CUB = Complement C1r/C1surchin epidermal growth factor-bone morphogenetic protein-1; $\mathrm{EGF}=$ epidermal growth factor; $\mathrm{CCP}=$ complement control protein.

Lipoteichoic acid is a cell wall component present in Gram-positive bacteria. The L-ficolin-MASP complex binds to immobilized lipoteichoic acid from clinically important bacteria, including Streptococcus pyogenes, Streptococcus agalactiae, and S. aureus, and activates C4 
[44]. The L-ficolin-MASP complex also binds to $N$-acetylneuraminic acid in the capsular polysaccharides of group B streptococci (S. agalactiae) of many serotypes, including serotype III, a common cause of neonatal sepsis and meningitis, and initiates neutrophil-mediated opsonophagocytosis in the presence of human serum [45]. As described above, L-ficolin recognizes $\beta$ - $(1 \rightarrow 3)$-D-glucan as well as acetyl groups. Upon binding to $\beta$ - $(1 \rightarrow 3)$-D-glucan, the L-ficolin-MASP complex activates the lectin pathway [9].

C-reactive protein is a plasma protein that binds to specific carbohydrates on the surface of microorganisms. $\mathrm{C} 1$ binds to $\mathrm{C}$-reactive protein through C1q, initiating the classical pathway without involvement of immunoglobulins. Recent studies have shown that L-ficolin interacts with C-reactive protein under conditions of local infection/inflammation, and this amplifies complement activation [46]. This finding suggests a collaboration of ficolins and C-reactive protein in innate immunity.

The H-ficolin-MASP complex binds to PSA derived from $A$. viridans coated on microplates and activates $\mathrm{C} 4$ [40]. It also exhibits in vitro bactericidal activity against A. viridans in the presence of human serum [47].

The recombinant M-ficolin-MASP complex binds to GlcNAc or acetylated compounds, resulting in C4 activation [24]. Since M-ficolin is found in plasma, it may function as a complement-activating ficolin in blood like Land $\mathrm{H}$-ficolin, although whether or not $\mathrm{M}$-ficolin in plasma is complexed with MASP remains to be elucidated. As described above, however, M-ficolin is reported to be expressed on U937 cells. Antibodies against the protein prevent these cells from phagocytosing $E$. coli, suggesting that $\mathrm{M}$-ficolin plays a role in innate immunity by acting as a lectin-like phagocytic receptor for pathogens [23]. Further research is required to clarify the physiologic roles of M-ficolin.

Recombinant ficolin A, but not ficolin B, binds to mouse MASP-2 and sMAP, resulting in complement activation [30]. These findings suggest that, similar to human $\mathrm{L}$-ficolin and $\mathrm{H}$-ficolin, ficolin $\mathrm{A}$ in serum functions as a recognition molecule in the lectin pathway, while ficolin B lacks such a function.

Human MBL-MASP has recently been reported to activate $\mathrm{C} 3$ not only via the lectin pathway, in which C3 convertase $\mathrm{C} 4 \mathrm{bC} 2 \mathrm{a}$ is formed, but without involvement of C2 [48]. The latter activation is dependent on the alternative pathway. Although the precise mechanisms underlying MBL-MASP-mediated activation of the alternative pathway are not known, MASPs such as MASP-1 may be involved in that activation. Whether or not ficolinMASP has a similar function to MBL-MASP remains unknown.

$\mathrm{C} 1$ inhibitor (C1-INH) is a protease inhibitor belonging to the serpin family. C1-INH inhibits $\mathrm{Clr}$ and $\mathrm{C} 1 \mathrm{~s}$ in the $\mathrm{C} 1$ complex by binding covalently to their active forms, thereby regulating the activation of the classical pathway. C1-INH also binds to MASP-1 and MASP-2 but not MASP-3 in the fluid phase. When the lectin pathway is activated via MBL-MASP, an MBL-MASP-C1-INH complex is formed [49]. Preliminary studies by the current authors have revealed that L-ficolin-MASP-C1-INH complex is formed upon activation of the lectin pathway via L-ficolin-MASP in human serum, which suggests that complement activation by ficolin-MASP and MBLMASP is regulated by C1-INH in a similar manner (unpubl. data).

Endo et al. have recently found that recombinant mouse ficolins and MBL enhance activation of the lectin pathway by interacting with fibrinogen and fibrin [50]. This implies that the lectin pathway collaborates with the coagulation system in immunity. This collaboration of these 2 systems is also seen in the proteolytic activity of MASP-1 with respect to coagulation components such as factor XIII and fibrinogen [51].

The components and functions of the lectin pathway and classical pathway are very similar. Collagenous lectins (ficolin and MBL) are associated with MASP of the MASP/C1r/C1s family in the former pathway, whereas $\mathrm{Clq}$ is associated with $\mathrm{Clr}$ and $\mathrm{C} 1 \mathrm{~s}$ in the latter pathway. Binding sites of the corresponding proteases of the MASP/ $\mathrm{C} 1 \mathrm{r} / \mathrm{C} 1 \mathrm{~s}$ family are located in the collagen-like domains of the lectins and C1q. C4 and $\mathrm{C} 2$ are activated by proteases of the MASP/C1r/C1s family in both pathways. However, the striking difference between the 2 pathways is that ficolin and MBL act as pattern recognition molecules in innate immunity and bind to carbohydrates on pathogens, whereas C1q binds to immunoglobulins in adaptive immunity. These findings suggest that the lectin pathway evolved into the classical pathway.

\section{Other Functions of Serum Ficolins}

The ability of L-ficolin to enhance the phagocytosis of S. typhimurium by neutrophils suggests that serum ficolins not only activate the lectin complement pathway but also act as opsonins [3]. In addition to their important role in innate immunity, ficolins are involved in apoptosis. Binding of serum ficolins to apoptotic cells activates 
the complement system and, consequently, generates opsonic C3 [52]. DNA is a potential L-ficolin ligand because it inhibits L-ficolin binding to late apoptotic and necrotic cells [53]. Similar to their role in innate immunity, ficolins have opsonin-like activity during apoptosis [54]. The opsonic activity of human ficolins might be mediated by receptors such as CR1 and cClq receptor/calreticulin on phagocytes.

Pig plasma ficolin $\alpha$ binds to and neutralizes porcine reproductive and respiratory viruses [55]. This finding indicates that ficolins in plasma/serum play a role in innate immunity through complement activation as well as antiviral and opsonic activity.

\section{Conclusions}

Binding specificity for carbohydrates seems to vary among ficolins. Apparently, however, the $\mathrm{N}$-acetyl group is recognized by a majority of ficolins. The carbohydrate GlcNAc contains an $N$-acetyl group and is widely distributed on the surface of microbes. Therefore, ficolins bind a variety of microbial pathogens bearing GlcNAc.

Accumulating evidence has shown that upon binding to the carbohydrates present on microbes, ficolins present in the serum, such as human L-ficolin, $\mathrm{H}$-ficolin and mouse ficolin A, activate the lectin complement pathway in association with MASP, thereby playing an important role as a pattern recognition molecule in innate immunity. The presence of ficolins in ascidian hemolymph plasma raises the possibility that these proteins play a role in defense against pathogens in invertebrates as well as vertebrates. Mouse ficolin B cannot form complexes with MASP-2, implying that ficolin B lacks the ability to activate complement. On the other hand, mouse ficolin $B$ is reported to aggregate $S$. aureus, which enhanced phagocytosis of the bacteria by macrophages [2]. Human H-ficolin in the lung is likely to act as an opsonin, similar to 2 types of pulmonary collectins (SP-A and SP-D), whereas serum $\mathrm{H}$-ficolin, which is associated with MASP, may have dual functions as both an opsonin and as an initiator of complement activation. Therefore, a major function of ficolins, regardless of whether or not they are complexed with MASP, may be to contribute to innate immunity by activating complement and/or enhancing phagocytosis and eliminating pathogens. The importance of ficolins in host defense is exemplified by the association of L-ficolin deficiency with premature, low birthweight neonates, and perinatal infections [56]. Taken together with the finding that ficolins are involved in apoptosis in vitro, ficolins are conceivably responsible for both host defense and homeostasis.

\section{References}

1 Ichijo H, Hellman U, Wernstedt C, Gonez LJ, Claesson-Welsh L, Heldin CH, Miyazono K: Molecular cloning and characterization of ficolin, a multimeric protein with fibrinogen- and collagen-like domains. J Biol Chem 1993;268:14505-14513

- Endo Y, Matsushita M, Fujita T: Role of ficolin in innate immunity and its molecular basis. Immunobiology 2007;212:371-379.

-3 Matsushita M, Endo Y, Taira S, Sato Y, Fujita T, Ichikawa N, Nakata M, Mizuochi T: A novel human serum lectin with collagenand fibrinogen-like domains that functions as an opsonin. J Biol Chem 1996;271:24482454.

4 Hummelshoj T, Thielens NM, Madsen HO, Arlaud GJ, Sim RB, Garred P: Molecular organization of human Ficolin-2. Mol Immunol 2007;44:401-411.

5 Endo Y, Sato Y, Matsushita M, Fujita T: Cloning and characterization of the human lectin P35 gene and its related gene. Genomics 1996;36:515-521.
Krarup A, Thiel S, Hansen A, Fujita T, Jensenius JC: L-ficolin is a pattern recognition molecule specific for acetyl groups. J Biol Chem 2004;279:47513-47519.

7 Faro J, Chen Y, Jhaveri P, Oza P, Spear GT, Lint TF, Gewurz H: L-ficolin binding and lectin pathway activation by acetylated lowdensity lipoprotein. Clin Exp Immunol 2008;151:275-283.

8 Krarup A, Mitchell DA, Sim RB: Recognition of acetylated oligosaccharides by human Lficolin. Immunol Lett 2008;118:152-156.

$\$ 9$ Ma YG, Cho MY, Zhao M, Park JW, Matsushita M, Fujita T, Lee BL: Human mannosebinding lectin and L-ficolin function as specific pattern recognition proteins in the lectin activation pathway of complement. J Biol Chem 2004;279:25307-25312.

10 Garlatti V, Belloy N, Martin L, Lacroix M, Matsushita M, Endo Y, Fujita T, FontecillaCamps JC, Arlaud GJ, Thielens NM, Gaboriaud C: Structural insights into the innate immune recognition specificities of $\mathrm{L}$ - and H-ficolins. EMBO J 2007;26:623-633.
11 Hummelshoj, T, Munthe-Fog L, Madsen HO, Fujita T, Matsushita M, Garred P: Polymorphisms in the FCN2 gene determine serum variation and function of Ficolin-2. Hum Mol Genet 2005;14:1651-1658.

12 Herpers BL, Immink MM, de Jong BA, van Velzen-Blad H, de Jongh BM, van Hannen EJ: Coding and non-coding polymorphisms in the lectin pathway activator L-ficolin gene in 188 Dutch blood bank donors. Mol Immunol 2006; 43:851-855.

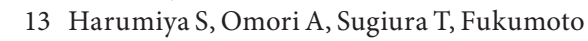
Y, Tachikawa H, Fujimoto D: EBP-37, a new elastin-binding protein in human plasma: structural similarity to ficolins, transforming growth factor-beta 1-binding proteins. J Biochem 1995;117:1029-1035.

14 Edgar PF: Hucolin, a new corticosteroidbinding protein from human plasma with structural similarities to ficolins, transforming growth factor-beta 1-binding proteins, FEBS Lett 1995;375:159-161. 
15 Inaba S, Okochi K: On a new precipitating antibody against normal human serum found in two patients with SLE (in Japanese). Igaku No Ayumi 1978;107:690-691.

- 16 Yae Y, Inaba S, Sato H, Okochi K, Tokunaga F, Iwanaga S: Isolation and characterization of a thermolabile $\beta-2$ macroglycoprotein ('thermolabile substance' or 'Hakata antigen') detected by precipitating (auto) antibody in sera of patients with systemic lupus erythematosus. Biochim Biophys Acta 1991; 1078:369-376.

- 17 Akaiwa M, Yae Y, Sugimoto R, Suzuki SO, Iwaki T, Izuhara K, Hamasaki N: Hakata antigen, a new member of the ficolin/opsonin p35 family, is a novel human lectin secreted into bronchus/alveolus and bile. J Histochem Cytochem 1999;47:777-785.

18 Kuraya M, Matsushita M, Endo Y, Thiel S, Fujita T: Expression of H-ficolin/Hakata antigen, mannose-binding lectin-associated serine protease (MASP)-1 and MASP-3 by human glioma cell line T98G. Int Immunol 2003;15:109-117.

19 Sugimoto R, Yae Y, Akaiwa M, Kitajima S, Shibata Y, Sato H, Hirata J, Okochi K., Izuhara K, Hamasaki N: Cloning and characterization of the Hakata antigen, a member of the ficolin/opsonin p35 lectin family. J Biol Chem 1998;273:20721-20727.

-20 Tsujimura M, Ishida C, Sagara Y, Miyazaki T, Murakami K, Shiraki H, Okochi K, Maeda Y: Detection of serum thermolabile beta-2 macroglycoprotein (Hakata antigen) by enzyme-linked immunosorbent assay using polysaccharide produced by Aerococcus viridans. Clin Diagn Lab Immunol 2001;8:454459.

$21 \mathrm{Lu}$ J, Tay PN, Kon OL, Reid KBM: Human ficolin: cDNA cloning, demonstration of peripheral blood leucocytes as the major site of synthesis and assignment of the gene to chromosome 9. Biochem J 1996;313:473478.

$22 \mathrm{Lu}$ J, Le Y, Kon OL, Chan J, Lee SH: Biosynthesis of human ficolin, an Escherichia colibinding protein, by monocytes: comparison with the synthesis of two macrophage-specific proteins, Clq and the mannose receptor. Immunology 1996;89:289-294.

23 Teh C, Le Y, Lee SH, Lu J: M-ficolin is expressed on monocytes and is a lectin binding to $\mathrm{N}$-acetyl-D-glucosamine and mediates monocyte adhesion and phagocytosis of Escherichia coli. Immunology 2000;101:225232.

24 Liu Y, Endo Y, Iwaki D, Nakata M, Matsushita M, Wada I, Inoue K, Munakata M, Fujita T: Human M-ficolin is a secretory protein that activates the lectin complement pathway. J Immunol 2005;175:3150-3156.

-25 Honoré C, Rørvig S, Munthe-Fog L, Hummelshøj T, Madsen HO, Borregaard N, Garred P: The innate pattern recognition molecule Ficolin-1 is secreted by monocytes/ macrophages and is circulating in human plasma. Mol Immunol 2008, 45:2782-2789.
26 Frederiksen PD, Thiel S, Larsen CB, Jensenius JC: M-ficolin, an innate immune defence molecule, binds patterns of acetyl groups and activates complement. Scand Immunol 2005;62:462-473.

27 Ohashi T, Erickson HP: Oligomeric structure and tissue distribution of ficolins from mouse, pig and human. Arch Biochem Biophys 1998;360:223-232.

28 Fujimori Y, Harumiya S, Fukumoto Y, Miura Y, Yagasaki K, Tachikawa H, Fujimoto D: Molecular cloning and characterization of mouse ficolin-A. Biochem Biophys Res Commun 1998;244:796-800.

29 Runza VL, Hehlgans T, Echtenacher B, Zahringer U, Schwaeble WJ, Mannel DN: Localization of the mouse defense lectin ficolin $B$ in lysosomes of activated macrophages. J Endotoxin Res 2006;12:120-126.

30 Endo Y, Nakazawa N, Liu Y, Iwaki D, Takahashi M, Fujita T, Nakata M, Matsushita M: Carbohydrate-binding specificities of mouse ficolin A, a splicing variant of ficolin A and ficolin $\mathrm{B}$ and their complex formation with MASP-2 and sMAP. Immunogenetics 2005; 57:837-844

31 Endo Y, Liu Y, Kanno K, Takahashi M, Matsushita M, Fujita T: Identification of the mouse $\mathrm{H}$-ficolin gene as a pseudogene and orthology between mouse ficolins A/B and human L-/M-ficolins. Genomics 2004;84: 737-744.

32 Matsushita M: The lectin pathway of the complement system. Microbiol Immunol 1996;40:887-893.

33 Sorensen R, Thiel S, Jensenius JC: Mannanbinding-lectin-associated serine proteases, characteristics and disease associations. Springer Semin Immunopathol 2005;27: 299-319.

34 Fujita T, Matsushita M, Endo Y: The lectincomplement pathway: its role in innate immunity and evolution. Immunol Rev 2004; 198:185-202.

35 Moller-Kristensen M, Thiel S, Sjoholm A, Matsushita M, Jensenius JC: Cooperation between MASP-1 and MASP-2 in the generation of $\mathrm{C} 3$ convertase through the MBL pathway. Int Immunol 2007;19:141-149.

-36 Takahashi M, Iwaki D, Kanno K, Ishida Y, Xiong J, Matsushita M, Endo Y, Miura S, Ishii N, Sugamura K, Fujita T: Mannosebinding lectin (MBL)-associated serine protease (MASP)-1 contributes to activation of the lectin complement pathway. J Immunol 2008;180:6132-6138.

37 Dahl MR, Thiel S, Matsushita M, Fujita T, Willis AC, Christensen T, Vorup-Jensen T, Jensenius JC: MASP-3 and its association with distinct complexes of the mannanbinding lectin complement activation pathway. Immunity 2001;15:127-135.
-38 Iwaki D, Kanno K, Takahashi M, Endo Y, Lynch NJ, Schwaeble WJ, Matsushita M, Okabe M, Fujita T: Small mannose-binding lectin-associated protein plays a regulatory role in the lectin complement pathway. J Immunol 2006;177:8626-8632.

39 Matsushita M, Endo Y, Fujita T: Cutting edge: complement-activating complex of ficolin and mannose-binding lectin-associated serine protease. J Immunol 2000;164: 2281-2284.

40 Matsushita M, Kuraya M, Hamasaki N, Tsujimura M, Shiraki H, Fujita T: Activation of the lectin complement pathway by $\mathrm{H}$-ficolin (Hakata antigen). J Immunol 2002; 168: 3502-3506.

41 Teillet F, Gaboriaud C, Lacroix M, Martin L, Arlaud GJ, Thielens NM: Crystal structure of the CUB1-EGF-CUB2 domain of human MASP-1/3 and identification of its interaction sites with mannan-binding lectin and ficolins. J Biol Chem 2008;283:2571525724.

42 Lacroix M, Dumestre-Pérard C, Schoehn G, Houen G, Cesbron JY, Arlaud GJ, Thielens NM: Residue Lys57 in the collagen-like region of human L-ficolin and its counterpart Lys47 in H-ficolin play a key role in the interaction with the mannan-binding lectinassociated serine proteases and the collectin receptor calreticulin. J Immunol 2009;182: 456-465.

43 Hummelshoj T, Fog LM, Madsen HO, Sim RB, Garred P: Comparative study of the human ficolins reveals unique features of Ficolin-3 (Hakata antigen). Mol Immunol 2008; 45:1623-1632.

44 Lynch NJ, Roscher S, Hartung T, Morath S, Matsushita M, Maennel DN, Kuraya M, Fujita T, Schwaeble WJ: L-ficolin specifically binds to lipoteichoic acid, a cell wall constituent of Gram-positive bacteria, and activates the lectin pathway of complement. J Immunol 2004;172:1198-1202.

45 Aoyagi Y, Adderson EE, Rubens CE, Bohnsack JF, Min JG, Matsushita M, Fujita T, Okuwaki Y, Takahashi S: L-ficolin/mannose-binding lectin-associated serine protease complexes bind to Group B Streptococci largely through $\mathrm{N}$-acetylneuraminic acid of capsular polysaccharide, and activate the complement pathway. Infect Immun 2008; 76:179-188.

46 Zhang J, Koh J, Lu J, Thiel S, Leong BS, Sethi $\mathrm{S}, \mathrm{He} \mathrm{CY}$, Ho B, Ding JL: Local inflammation induces complement crosstalk which amplifies the antimicrobial response. PLoS Pathog 2009;5:e1000282.

47 Tsujimura M, Miyazaki T, Kojima E, Sagara Y, Shiraki H, Okochi K, Maeda Y: Serum concentration of Hakata antigen, a member of the ficolins, is linked with inhibition of Aerococcus viridans growth. Clin Chim Acta 2002;325:139-146. 
-48 Selander B, Martensson U, Weintraub A, Holmstrom E, Matsushita M, Thiel S, Jensenius JC, Truedsson L, Sjoholm AG: Mannanbinding lectin activates $\mathrm{C} 3$ and the alternative complement pathway without involvement of C2. J Clin Invest 2006;116:14251434.

-49 Petersen SV, Thiel S, Jensen L, Vorup-Jensen T, Koch C, Jensenius JC: Control of the classical and the MBL pathway of complement activation. Mol Immunol 2000;37:803-811.

50 Endo Y, Nakazawa N, Iwaki D, Takahashi M, Matsushita M, Fujita T: Interactions of ficolin and mannose-binding lectin with fibrinogen/fibrin augment the lectin complement pathway. J Innate Immun DOI: $\underline{10.1159 / 000227805 .}$.
1 Presanis JS, Hajela K, Ambrus G, Gál P, Sim RB: Differential substrate and inhibitor profiles for human MASP-1 and MASP-2. Mol Immunol 2004;40:921-929.

-52 Kuraya M, Ming Z, Liu X, Matsushita M, Fujita T: Specific binding of L-ficolin and $\mathrm{H}$-ficolin to apoptotic cells leads to complement activation. Immunobiology 2005;209:689697.

53 Jensen ML, Honoré C, Hummelshøj T, Hansen BE, Madsen HO, Garred P: Ficolin-2 recognizes DNA and participates in the clearance of dying host cells. Mol Immunol 2007; 44:856-865.

54 Honoré C, Hummelshoj T, Hansen BE, Madsen $\mathrm{HO}$, Eggleton P, Garred P: The innate immune component ficolin 3 (Hakata antigen) mediates the clearance of late apoptotic cells. Arthritis Rheum 2007;56:1598-1607.
55 Keirstead ND, Lee C, Yoo D, Brooks AS, Hayes MA: Porcine plasma ficolin binds and reduces infectivity of porcine reproductive and respiratory syndrome virus (PRRSV) in vitro. Antiviral Res 2008;77:28-38.

56 Swierzko AS, Atkinson AP, Cedzynski M, Macdonald SL, Szala A, Domzalska-Popadiuk I, Borkowska-Klos M, Jopek A, Szczapa J, Matsushita M, Szemraj J, Turner ML, Kilpatrick DC: Two factors of the lectin pathway of complement, L-ficolin and mannan-binding lectin, and their associations with prematurity, low birthweight and infections in a large cohort of Polish neonates. Mol Immunol 2009;46:551-558. 